\begin{tabular}{ll}
\hline \hline MINING AND METALLURGY INSTITUTE BOR & ISSN: 2334-8836 (̌̌tampano izdanje) \\
UDK: 622 & ISSN: 2406-1395 (Online) \\
\hline \hline
\end{tabular}

\title{
THE USE OF SCRIPT IN THE SOFTWARE GEMCOM ${ }^{* * *}$
}

\begin{abstract}
Scripts are essentially the macros containing instructions for data manipulation in the form of mathematical and logical operations performed for the block model data.

In order to create the useful filters and key indices, it is important to have a good understanding of expressions and how to use them. Expressions are simple formulae that can be created to define selection criteria for data in the workspace. There are two types of expressions: math expressions, which always result in a numeric value, and logical expressions, which always result in a true or false condition.

Math expressions consist of up to three components: field specifiers, constants, and math operators.

Logical expressions are made up of two math expressions separated by a logical operator.

Keywords: scripts, logical expressions, mathematical and logical operations, block model
\end{abstract}

\section{INTRODUCTION}

The geological block model is a threedimensional row of cubes (mini blocks) or matrixes, which are used for modeling the mineral deposits and other structures that are located beneath the ground surface. Those can be the amorphous ore bodies such as the mainly metallic ore deposits or layered for stratigraphic deposits.

Standard block model that is commonly used in geological modeling of deposit, consists of the following attributes (block models):

- Rock Type, or lithological block model

- Density model or specific mass model (weight)

- Elevation model or model of grids

- Grade model or model of content, which can be more than one, depending on the number of useful elements in the mineral raw material
- Percentage or partial model, if necessary

- Other attributes (models) as desired by the user

Block model geometry: Block model is spatially defined by three axes - X, Y, Z, and the start of the block model by point called the "origin" and is determined by the specified values $\mathrm{x}, \mathrm{y}, \mathrm{z}$. If we accept conventionnally that the block model is a cube or parallelepiped composed of smaller elements, and the condition is that these elements - mini blocks have the same dimensions along the $z$ axis, and observe it in space, the growing trends of rows, columns and levels from the origin that is located in the upper left corner of the block model, i.e. cube. Which space will be affected by the block model, depending on the size and number of mini-blocks.

\footnotetext{
*Mining and Metallurgy Institute Bor, zoran.vaduveskovic@irmbor.co.rs

*** Technical Faculty Bor, University of Belgrade

**** This work is the result of the Project TR33038 "Improvement of Copper Ore Mining and Processing Technology with Monitoring of Living and Working in RTB-BOR Group ", funded by the Ministry of Education, Science and Technological Development of the Republic of Serbia
} 


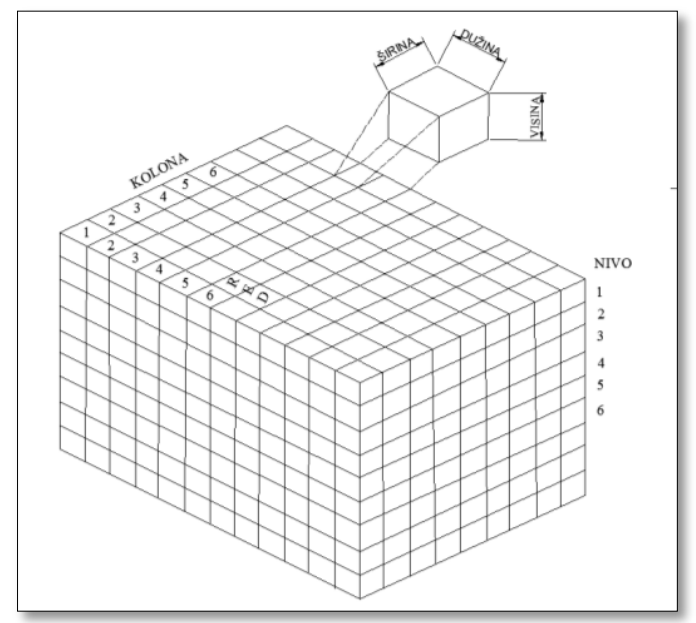

Figure 1 Schematic view of a block model with elements

\subsection{Data manipulation in block models}

It allows easy creation and evaluation of the new models as part of the existing one. Existing models such as the models of grade, rock types, density, etc., are often not sufficient, for example a detailed assessment of reserves. Purposes often occur in Gemcom:

- to create a model of equivalent grade for many metallic deposits or equivalent grade for determination the cut-off grade,

- to find relations between various elements (for example,

$\mathrm{Ca} / \mathrm{Mg}$ indicators) for various operations in the design of open pit,

- to develop the sophisticated Rock Type models, where codes of rock types depend on content in one or more of block models,

- to create the complex density models (if the density is assumed as a function of rock types and contents, etc.),

- to convert the block models from one set of units into another, etc.

Manipulation allows performing the global changes and rewriting the whole block model. Thewhole new models can be created as complex combinations of the existing models or selectively change the data in the model using the conditional logic. Manipulation of the block model is a powerful tool, but it must be used properly. Errors can permanently damage data in the block model.

\subsection{Scripts}

Scripts are essentially macros containing instructions for manipulation in the form of mathematical and logical operations that are performed for the specified block models. Scripts can be short and simple or very long duration and included, depending on the needs.

They are written using GSI script language.

\section{EDITING PROCEDURE BY SCRIPTS}

In the basic software - Gemcom, an additional attribute or generic block model is firstly created within the block model (CKB-BL). Data are stored in this block 
model that will be obtained by manipulation of the existing data in the block model attributes. For example, if in the block model there is an attribute blm of total copper $(\mathrm{Cu})$, and also attribute blm of oxide copper $\left(\mathrm{C}_{\mathrm{uox}}\right)$, created by interpolation of data from the exploration drill holes after certain procedure and geostatistical data processing, if the sulphide copper block model is needed with $10 \%$ oxide $\left(\mathrm{Cu}_{\mathrm{S}}(10 \% \mathrm{OX})\right.$, the same can be obtained by data manipulation using the script.

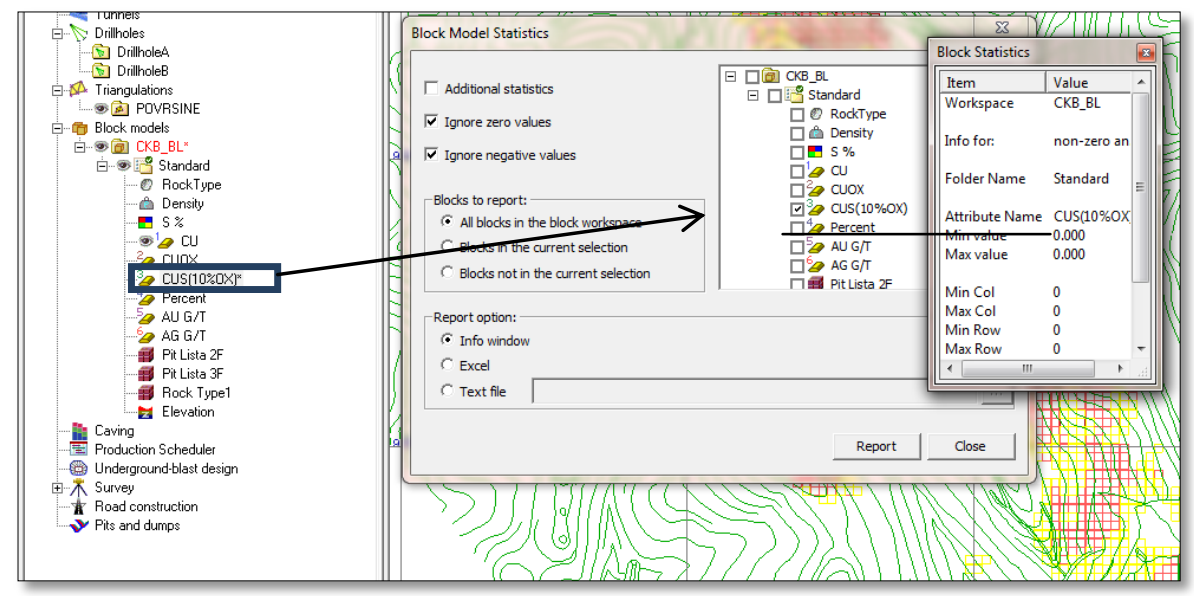

Figure 2 Statistics of block model before editing by script, which shows that they are in the attribute, processed by the value " 0 "

Commands in software for editing the block model are shown below:

\section{Commands: Block $\rightarrow$ Edit $\rightarrow$ Simple Manipulation / Advanced Manipulation}

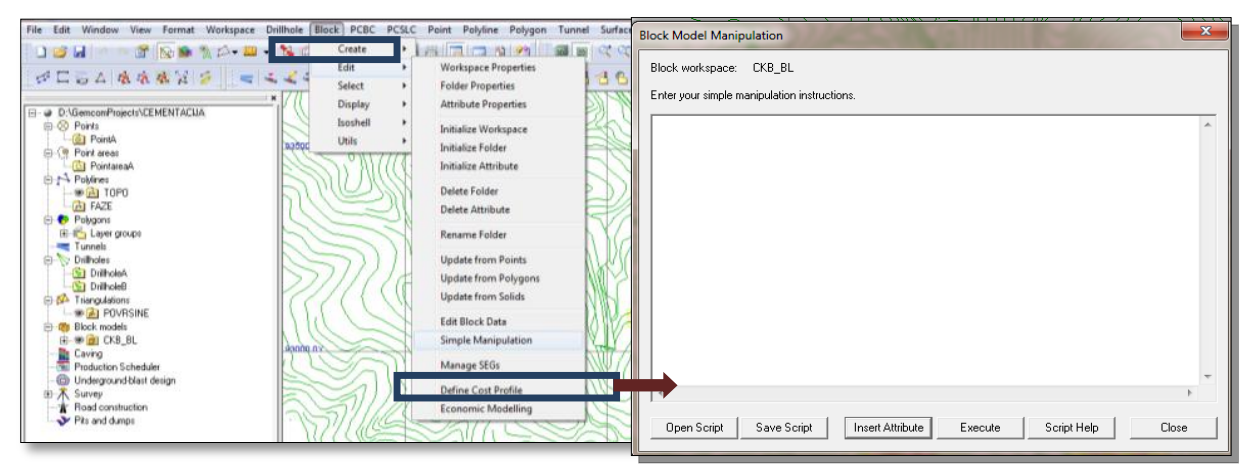

Figure 3 Input into the block model manipulation editor

The shown procedure opens the manipulation editor, where the attributes have to be inserted whose data will be used for manipulation and opening of prepared script, or macro, that is the system of mathematical and locial expressions: 


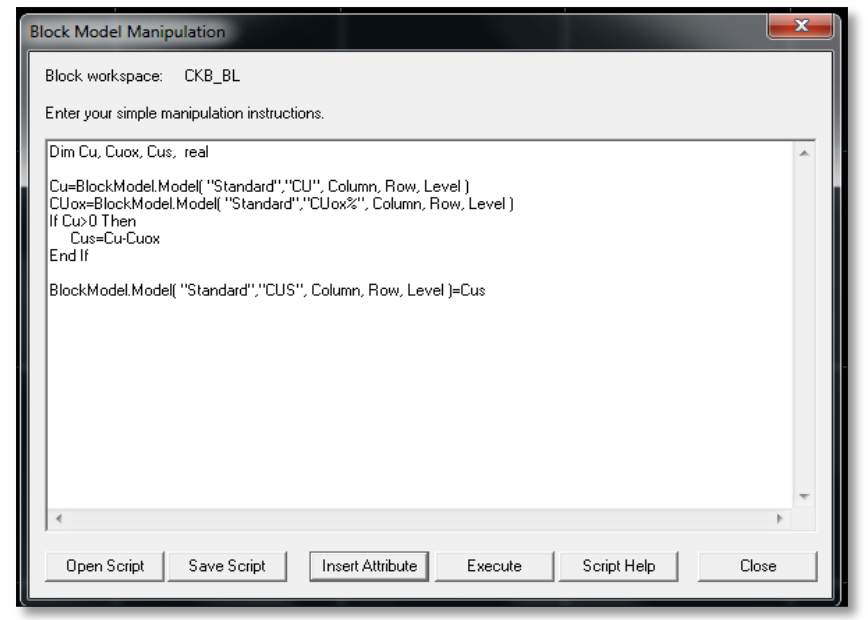

Figure 4 Script opening - script input into the block model manipualation editor

\subsection{Some examples of script:}

\section{$\underline{\text { Script } 1 \text { for } \mathrm{Cus}=\mathrm{Cu} \text { total }-\mathrm{Cu} \text { ox }}$}

Dim Cu, Cuox, Cus, real

$\mathrm{Cu}=$ BlockModel.Model("Standard", "Cu

\% Grade", Column, Row, Level)

Cuox=BlockModel.Model("Standard","

Cuox \% Grade", Column, Row, Level)

If $\mathrm{Cu}>0$ Then

$\mathrm{Cus}=\mathrm{Cu}-\mathrm{Cuox}$

End If

BlockModel.Model ("Standard", "Cus

\%", Column, Row, Level) $=$ Cus

Dim Cu, Cuox, PrCUOX, real

\section{Script 2}

Cu=BlockModel.Model("Standard", "C U\%", Column, Row, Level)

Cuox=BlockModel.Model("Standard", "CUOX \%", Column, Row, Level)

If $\mathrm{Cu}>0$ Then

$\operatorname{PrCUOX}=100 *(\mathrm{Cuox} / \mathrm{Cu})$

End If

BlockModel.Model("Standard", "PrCU

$O X^{\prime \prime}$, Column, Row, Level) $=\operatorname{PrCUOX}$

\section{Script 3}

$\operatorname{Dim} C u$, Cuox, $N$, real

$\mathrm{Cu}=$ BlockModel.Model("Standard", "Cu
\% Grade", Column, Row, Level) Cuox=BlockModel.Model("Standard"," Cuox \% Grade", Column, Row, Level) If $\mathrm{Cuox}>\mathrm{Cu}$ Then

$$
\mathrm{N}=\mathrm{Cu}
$$

Else $N=C u o x$

End if

BlockModel.Model("Standard", "Cuox \% Grade", Column, Row, Level) $=N$

\section{Script 4 Cu eqivalent}

$\mathrm{DIMCu}, \mathrm{Au}, \mathrm{Ag}$

$\mathrm{Cu}=$ BlockModel.Model("Standard", "Cu $\%$ Grade", Column, Row, Level)

Au=BlockModel.Model("Standard", "Au g/t Grade", Column, Row, Level) Ag=BlockModel.Model("Standard", "Ag g/t Grade", Column, Row, Level) If $\mathrm{Cu}>0.0999$ Then

Cueq $=C u+0.375 * A u+0.00206 * A g$

Else

Cueq $=0$

End If

BlockModel.Model("Standard", "Cueq \% Grade", Column, Row, Level) $=$ Cueq 


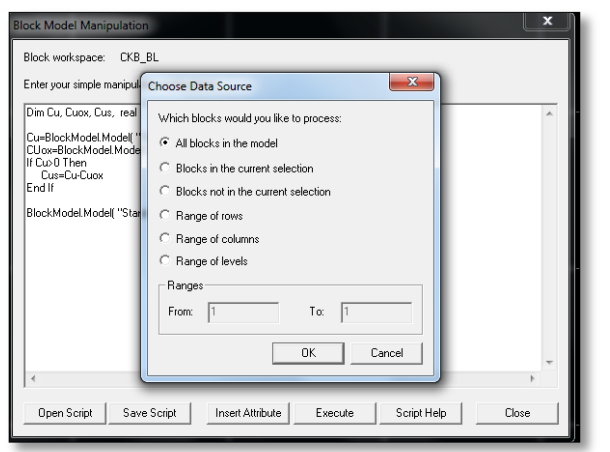

1

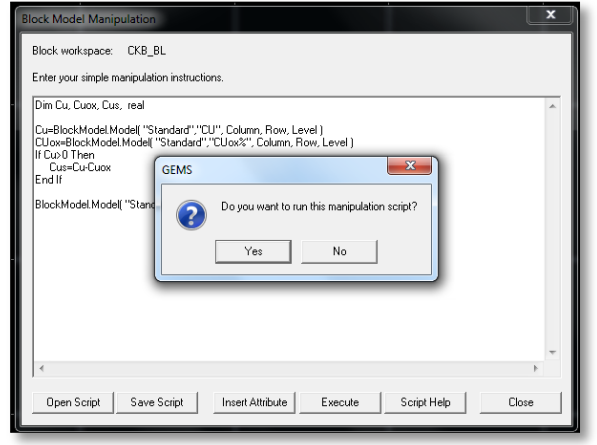

2

Figure 5 Further procedure of editing

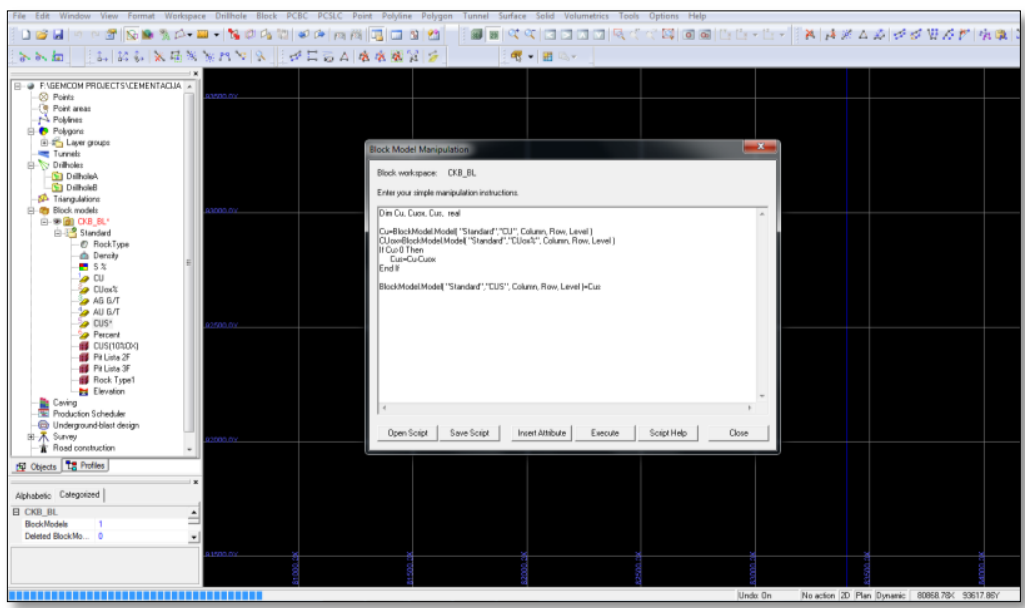

Figure 6 Process of block model editing

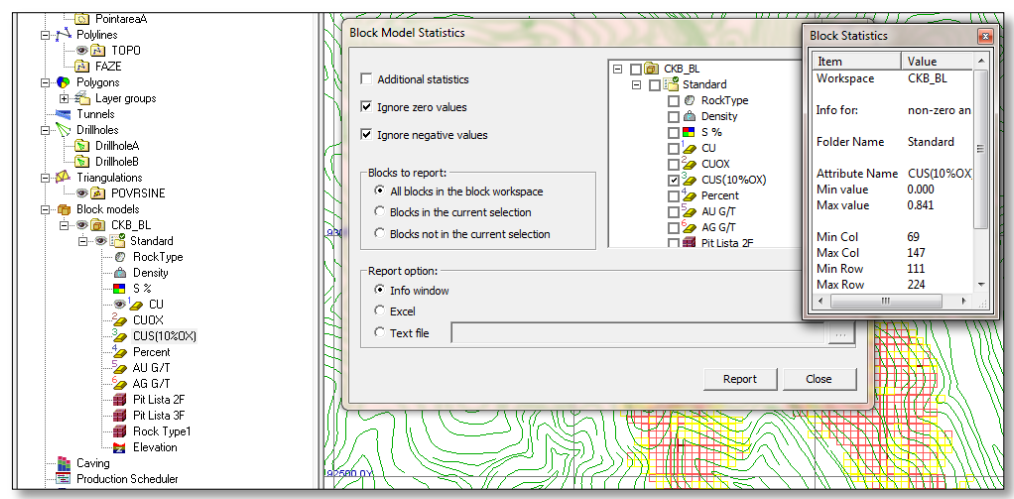

Figure 7 Statistics of block model after editing by script; data are generated in the attribute that is processed 


\subsubsection{Table of script types}

Table 1 Data types

\begin{tabular}{|lllc}
\hline \multicolumn{2}{|c}{ Data Types } & & \\
\cline { 2 - 4 } Variable & & Type Declaration & Size \\
\hline Byte & & Dim BVar As Byte & 0 to 255 \\
Boolean & & Dim BoolVar As Boolean & True or False \\
String & $\$$ & Dim Str_Var As String & 0 to 65,500 char \\
Integer & $\%$ & Dim Int_Var As Integer & 2 bytes \\
Long & $\&$ & Dim Long_Var As Long & 4 bytes \\
Single & $!$ & Dim Sing_Var As Single & 4 bytes \\
Double & $\#$ & Dim Dbl_Var As Double & 8 bytes \\
Variant & & Dim X As Any & 8 bytes \\
Currency & & Dim Cvar As Currency & 4 bytes \\
Object & & Dim X As Object & 8 bytes \\
Date & Dim D As Date & size of each element \\
\hline
\end{tabular}

\subsubsection{Mathematical operations used in scripts}

Table 2 Mathematical operators

\begin{tabular}{|l|l|}
\hline+ & Addition. \\
\hline- & Subtraction. \\
\hline$*$ & Multiplication. \\
\hline$I$ & Division. \\
\hline$\wedge$ & Exponentiation. \\
\hline LOG & Logarithm to base 10. \\
\hline LN & Logarithm to base E. \\
\hline$($ ) & Parentheses for grouping. \\
\hline
\end{tabular}

\subsection{Theoretical settings of data} manipulation using mathematical and logical expressions

This type of data manipulation uses two sets of mathematical expressions to manipulate in records selected by logical expressions. Conditional manipulation has the following form:

If .> Logical expression $>$ is TRUE

THEN Result $=\langle$ math expression 1$\rangle$

ELSE Result $=\langle$ math expression 2>

In logical expression, if logical expression is:

- TRUE, then GEMS uses the first set of mathematical expressions.
- False, then GEMS uses the second set of mathematical expressions.

\section{Mathematical expressions}

They consist of combinations with one operator. The result of mathematical expression is always a numeric value.

\section{$\underline{\text { Syntax }}$}

General syntax of mathematical expressions is in the following form:

$<$ Descriptor $>$ [<Operator $><$ Descriptor $>$ ] 
where:

<Descriptor> consists of specifiers of variables or constants field.

$<$ Operator> consists of any mathematical or trigonometric operator.

\section{Mathematical operators.}

Mathematical operators perform simple mathematical operations in numeric fields (integer, real, double, coordinate, angle, date) and constants (integer number) and generate the numerical result. GEMS can interprete the following mathematical operators:

Logical expression. Always results in TRUE or FALSE conditions, and consists of two mathematical expressions separated by logical expression.

\section{Logical operator}

Logical expressions consist of mathematical expressions and logical operators. The results of logical expression is either TRUE or FALSE. When it is used in data manipulation, the result TRUE means that the first mathematical expressions will be used, and FALSE means that the second mathematical expression will be used.

Syntax.

Generalized syntax of logical expression has the following form:

$<$ Mathematical expression> <Operator $><$ Mathematical expression $>$ where:

< Mathematical expression > consists of mathematical equation as defined above

$<$ Operator> consist of logical operator.

Examples.

Here are examples of logical expressions:

"ASSAYS:GOLD" LE 1.5

("ASSAYS:TO" - "ASSAYS:FROM") * COS ("ASSAYS:DIP") GT 10.0

Logical operators.

GEMS has the following logical operators that are used to compare two expressions:
1. LT. If the result of the first expression (equation) is smaller than the results of the second equation, logical operation is TRUE.

2. LE. If the results of the first equation is smaller or equal to the result of the second, logical operation is TRUE.

3. GT. If the results of the first equation is larger than the result of the second, logical operation is TRUE.

4. GE. If the results of the first equation is larger or equal to the result of the second equation, logical operation is TRUE

5. EQ. If the results of the first equation is equal to the result of the second equation, logical operation is TRUE.

6. NE. If the results of the first equation is not equal to the result of the second equation, logical operation is TRUE.

There are other logical operators that can be used when one wants to compare more than two logical expressions simultaneously:

- AND. Combines the results of two logical expressions. The end result is TRUE if the result of both logical expressions is TRUE.

- OR. Combines the results of two logical expressions. The end result is true if none of the results of these two logical expressions is not TRUE.

When it is wanted to use more than one logical expression at one time, each set of logical expressions must be limited by parentheses:

("ASSAYS:GOLD" GE 1.0) AND ("ASSAYS:SILVER" GE 5.0)

In mathematical equations and logical expressions, Gems performs operations in a specific order.

\section{CONCLUSION}

Scripts are used for manipulation of geological and geodetic data in the software using such data, and that on the basis of 


\section{REFERENCES}

known data sets, created subsets, according to the certain rules and procedures. This is a type of macro that has application in theother software that operate with mathematical expressions and data, and here is shown the usage in geological block model in the software Gemcom. Based on known data from two attributes that can be conditionally called the subsets of block model in the base of geological data, for example metal content, if it is a model of metallic deposit, a block model of equivalent $\mathrm{Cu}$ content can be created, if there are attributes of many metals ( $\mathrm{Au}, \mathrm{Ag}, \mathrm{Mo}$, etc.) in the model, or as in the example presented in the article - if the chemical analyses were carried out of core samples on total copper $\mathrm{Cu}$ and oxide $(\mathrm{Cu}$ ox $)$, and it is necessary to calculate the sulphide Cus; using the script will solve this in a very elegant way.

Scripts are in fact short records of linear programming used for writing the instructions for data manipulation.
[1] GEMS Block Modeling Manuel, ver 6.1., Gemcom Software International Inc. Vancouwer, BC. Canada, June 2007;

[2] Gems Software "Help";

[3] B. Kolonja et al., "Modeling of Deposits Using the Modern Tools" Script for the Open Pit Designs, Faculty of Mining and Geology, Belgrade, 2012;

[4] Z. Vaduvesković and others, "A Review of Previous Exploratory Works in the Complex Cerovo Cementacija and Data Processing in the Software Gemcom", 43 ${ }^{\text {rd }}$ International October Conference on Mining and Metallurgy, Kladovo, Serbia, October 12-15, 2011, pp. 515-520;

[5] Z. Vaduvesković, N. Vušović, D. Kržanović: "Analysis the Possibility for Improvement the Economic Indexes for Mining the Deposit Cementacija Kraku Bugaresku - Ore Field Cerovo", Mining and Metallurgy Institute Bor, 1/2014, pp. 13-24. 


\begin{tabular}{ll}
\hline \hline INSTITUT ZA RUDARSTVO I METALURGIJU BOR & ISSN: 2334-8836 (Štampano izdanje) \\
UDK: 622 & ISSN: 2406-1395 (Online) \\
\hline \hline
\end{tabular}

UDK: 681.51:551:517.1(045)=163.41

doi:10.5937/MMEB1504053V

Zoran Vaduvesković, Daniel Kržanović, Milenko Ljubojev", Nenad Vušović ${ }^{* *}$

KORIŠĆENJE SKRIPTA U SOFTVERU GEMCOM****

Izvod

Skripta su u suštini makroi koji sadrže uputstva u obliku matematičkih i logičkih operacija, za manipulacije podacima iz blok modela.

Da bi kreirali korisne filtere i ključne indikatore, važno je imati dobro razumevanje izraza i kako ih koristiti. Izrazi su jednostavne formule koje se mogu kreirati da bi se definisali kriterijumi za selekciju podataka u radnom prostoru - workspace-u ili radnoj bazi podataka. Postoje dve vrste izraza: matematički izrazi, koji uvek kao rezultat imaju brojčane vrednosti, i logični izraza, koji uvek rezultiraju istinito ili lažno stanje.

Matematički izrazi se sastoje od do tri komponente specifikatora polja, konstante, i matematičkog operatera.

Logički izrazi se sastoje od dva matematička izraza odvojenih logičkim operatorom.

Ključne reči: skripta, logički izrazi, matematički i logički operatori, blok model

\section{UVOD}

Geološki blok model je trodimenzionalni niz kockica (mini blokova) ili i matrica, koje se koriste za modeliranje ležišta mineralnih sirovina i drugih struktura koje se nalaze ispod površine terena. To mogu biti amorfna rudna tela kao što su uglavnom metalična rudna ležišta ili slojevita za stratigrafska ležišta.

Standardni blok model koji se najčešće koristi kod geološkog modeliranja ležišta, sastoji se od sledećih atributa (blok modela):

- Rock Type, ili litološki blok model

- Density model ili model specifične mase (težine)

- Elevation model ili model gridova,

- Grade model ili model sadržaja, kojih može biti više od jednog, zavisno od broja korisnih elemenata u mineralnoj sirovini,
- Procentualni ili parcijalni model, ako je potreban,

- Drugi atributi (modeli) po želji korisnika.

Geometrija blok modela: Blok model je prostorno definisan trima osama - X, Y, Z, a početak blok modela tačkom koja se naziva „origin“ i određena je navedenim vrednostima x, y, z. Ako prihvatimo konvencionalno da je blok model kocka ili paralelopiped sastavljen od manjih elemenata, a uslov je da ti elementi - mini blokovi, imaju jednake dimenzije po $z$ osi, i posmatramo ga $u$ prostoru, rastući pravci redova, kolona i nivoa su od origina koji se nalazi u levom gornjem uglu blok modela, tj. kocke. Koji će prostor biti zahvaćen blok modelom, zavisi od dimenzija i broja mini blokova.

\footnotetext{
* Institut za rudarstvo i metalurgiju Bor, zoran.vaduveskovic@irmbor.co.rs

** Tehnički fakultet Bor, Univerzitet u Beogradu

**** Ovaj rad je proistekao iz projekta TR33038, „Usavršavanje tehnologije eksploatacije i prerade rude bakra sa monitoringom životne i radne sredine u RTB-BOR grupa“, koji je finansiran sredstvima Ministarstva prosvete, nauke i tehnološkog razvoja Republike Srbije
} 


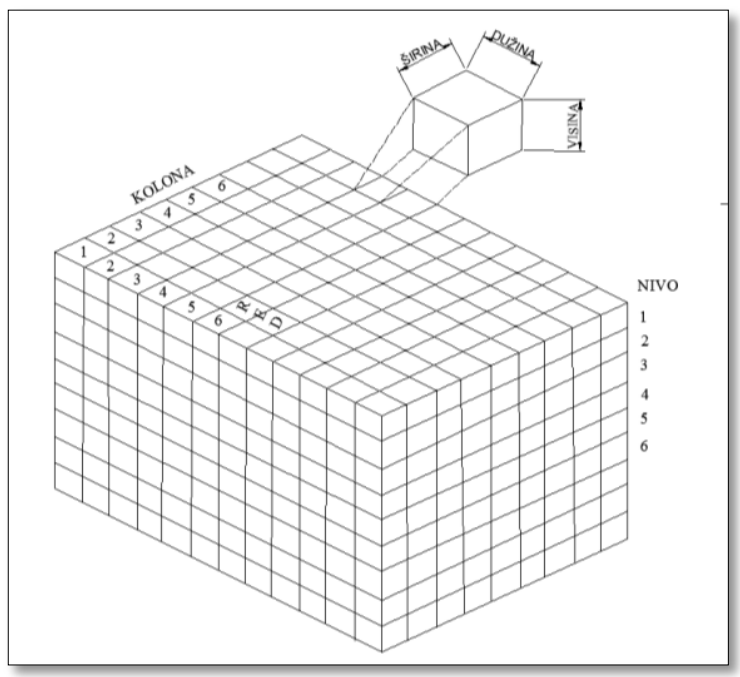

Sl. 1. Šematski prikaz blok modela sa elementima

\subsection{Manipulacija podacima $u$}

\section{blok modelima}

Omogućava jednostavno kreiranje i evaluaciju novih modela u sklopu postojećeg. Postojeći modeli kao što su modeli sadržaja, tipova stena, gustine, i dr., često nisu dovoljni za npr. detaljnu procenu rezervi. U Gemcomu se često javljaju potrebe:

- da se kreira model ekvivalentnog sadržaja za više metalničnih depozita, ili ekvivalentni sadržaji za određivanje graničnog sadržaja (cut-offgrade),

- da se nadju odnosi različitih elemenata (na primer, $\mathrm{Ca} / \mathrm{Mg}$ pokazatelji) za razne operacije u projektovanju kopova,

- da se izrade sofisticirani Rock Type modeli, gde kodovi vrste stena zavise od sadržaja u jednom ili više blok modela,

- da se kreiraju složeni modeli gustine (ako je gustina pretpostavljena kao funkcija tipova stena i sadržaja, i sl.),

- konvertuju blok modeli iz jednog skupa jedinica u drugu i dr.

Manipulacija omogućava da se izvrše globalne izmene i prepravi ceo blok model. Mogu da se kreiraju čitavi novi modeli kao kompleksne kombinacije postojećih modela ili selektivno promene podaci u modelu pomoću uslovne logike. Manipulacija Blok modelom je moćan alat, ali mora da se koristi pravilno. Greške mogu trajno da oštete podatke u blok modelu.

\subsection{Skripte (Scripts)}

Skripta su u suštini makroi koji sadrže uputstva za manipulacije u obliku matematičkih i logičkih operacija koje se obavljaju za navedene blok modele. Skripta mogu biti kratka i jednostavna ili veoma dugog trajanja i uključena, zavisno od potreba.

Pišu se koristeći GSI script language.

\section{PROCEDURA EDITOVANJA SKRIPTAMA}

U osnovnom softveru - Gemcom-u, najpre se kreira dodatni atribut ili generic blok model u sklopu blok modela (CKBBL). U tom blok modelu se smeštaju podaci koji će se dobiti manipulacijom postojećih 
podataka u atributima blok modela. Na primer, ako u blok modelu postoji atribut blm ukupnog bakra $(\mathrm{Cu})$, takodje $\mathrm{i}$ atribut blm oksidnog bakra $\left(\mathrm{C}_{\text {uox }}\right)$, koji su kreirani interpolacijom podataka iz istražnih bušotina nakon određene procedure i geostatističke obrade podataka, ukoliko je potreban i blok model sulfidnog bakra sa $10 \%$ oksidnog $\left(\mathrm{Cu}_{\mathrm{s}}(10 \% \mathrm{OX})\right.$, isti se može dobiti manipulacijom podataka korišćenjems skripta.

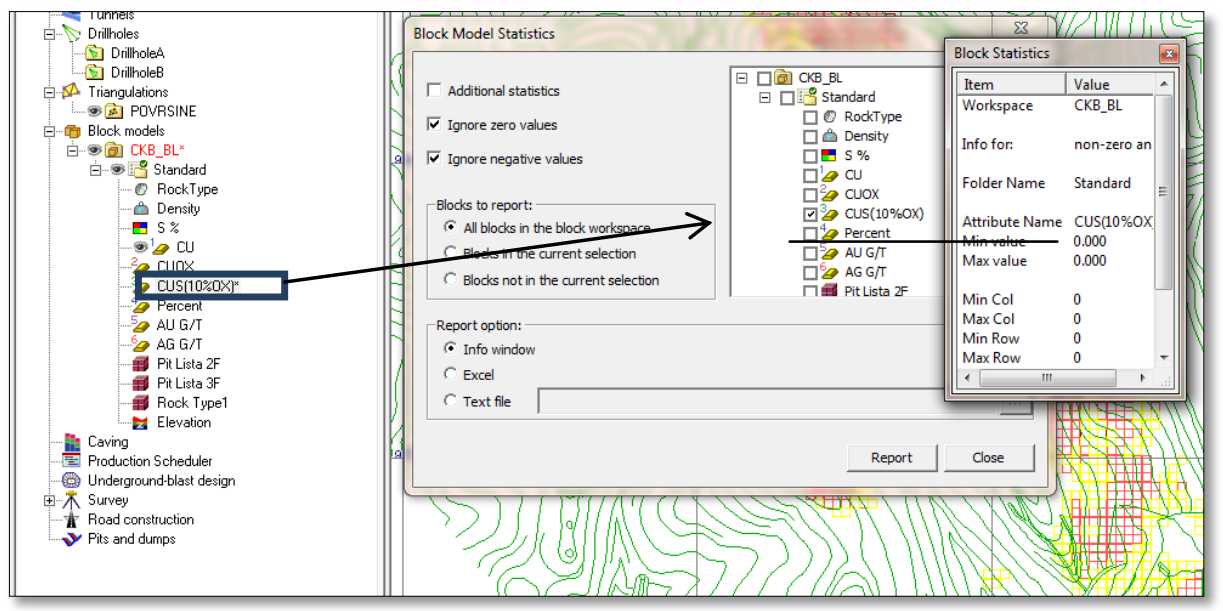

Sl. 2. Statistika blok modela pre editovanja skriptom, gde se vidi da su u atributu koji se obraduje vrednosti "O"

Komande u softveru kojima se vrši editovanje blok modela su prikazane u nastavku:
Komande: Block $\rightarrow$ Edit $\rightarrow$ Simple Manipulation / Advanced Manipulation

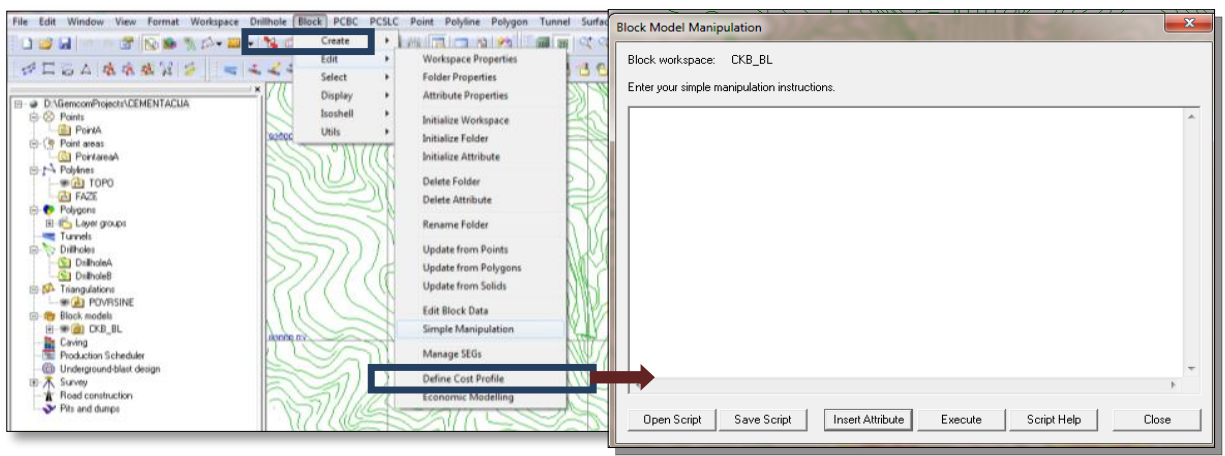

Sl. 3. Ulazak $u$ blok model manipulation editor

Prikazana procedura otvara editor $z a$ manipulaciju, gde treba insertovati atribute čijim će se podacima manipulisati i otvoriti pripremljeni skript, ili makro, odnosno sistem matematičkih i logičkih izraza: 


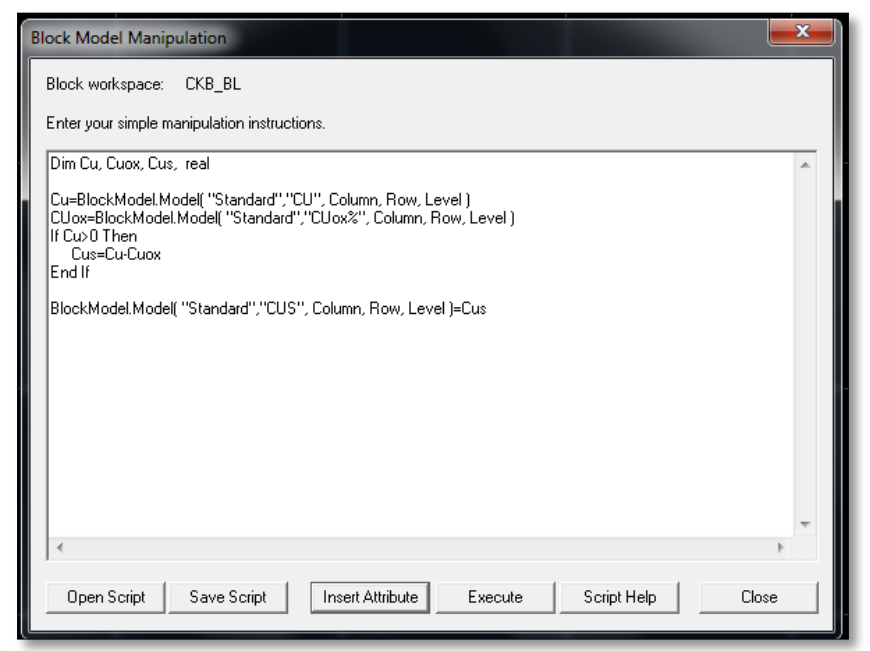

Sl. 4. Otvaranje skripte - unos skripte u blok model manipualation editor

\subsection{Neki primeri skripta:}

\section{$\underline{\text { Skripta 1. za Cus }=\mathrm{Cu} \text { ukupno }-\mathrm{Cu} \text { ox }}$}

Dim Cu, Cuox, Cus, real

$\mathrm{Cu}=$ BlockModel.Model("Standard", "Cu

$\%$ Grade", Column, Row, Level)

Cuox=BlockModel.Model("Standard","

Cuox\% Grade", Column, Row, Level)

If $\mathrm{Cu}>0$ Then

Cus $=$ Cu-Cuox

End If

BlockModel.Model ("Standard", "Cus

\%", Column, Row, Level) $=$ Cus

Dim Cu, Cuox, PrCUOX, real

\section{Skripta 2}

Cu=BlockModel.Model("Standard", "C

U\%", Column, Row, Level)

Cuox=BlockModel.Model("Standard", "CUOX \%", Column, Row, Level)

If $\mathrm{Cu}>0$ Then

$\operatorname{PrCUOX}=100 *(\mathrm{Cuox} / \mathrm{Cu})$

End If

BlockModel.Model("Standard", "PrCU OX", Column, Row, Level) $=\operatorname{PrCUOX}$

\section{Skripta 3.}

Dim Cu, Cuox, N, real

$\mathrm{Cu}=$ BlockModel.Model("Standard", "Cu
\% Grade", Column, Row, Level)

Cuox=BlockModel.Model("Standard","

Cuox \% Grade", Column, Row, Level)

If Cuox $>\mathrm{Cu}$ Then

$$
\begin{aligned}
& N=C u \\
& \text { Else } \\
& N=C u o x
\end{aligned}
$$

End if

BlockModel.Model("Standard", "Cuox \% Grade", Column, Row, Level) $=N$

\section{Skripta 4. Cu ekvivalent}

$\mathrm{DIMCu}, \mathrm{Au}, \mathrm{Ag}$

$\mathrm{Cu}=$ BlockModel.Model("Standard", "Cu

\% Grade", Column, Row, Level)

Au=BlockModel.Model("Standard", "Au g/t Grade", Column, Row, Level)

Ag=BlockModel.Model("Standard", "Ag g/t Grade", Column, Row, Level)

If $\mathrm{Cu}>0.0999$ Then

Cueq $=C u+0.375 * A u+0.00206 * A g$

Else

Cueq $=0$

End If

BlockModel.Model("Standard", "Cueq \% Grade", Column, Row, Level) $=$ Cueq 


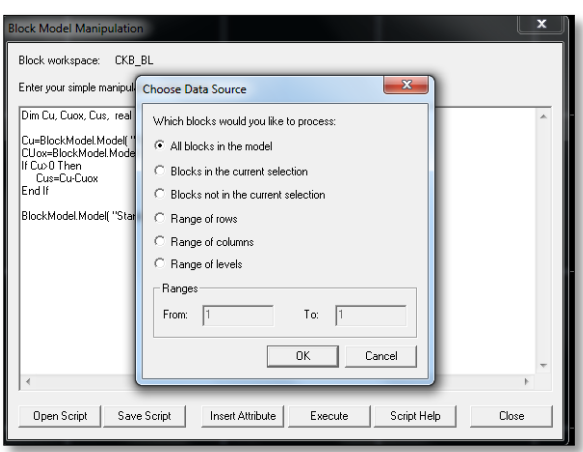

1

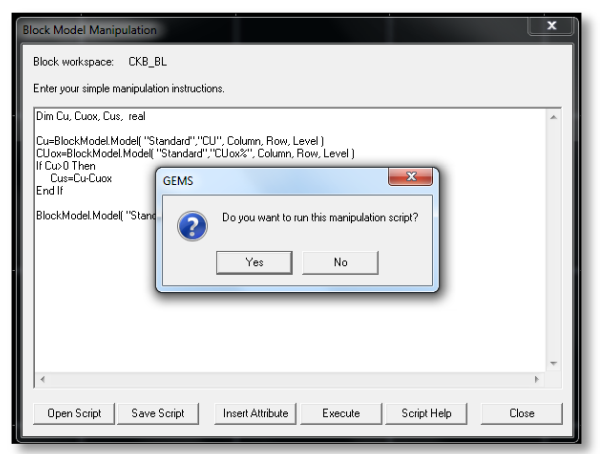

2

SI. 5. Dalji postupak editovanja

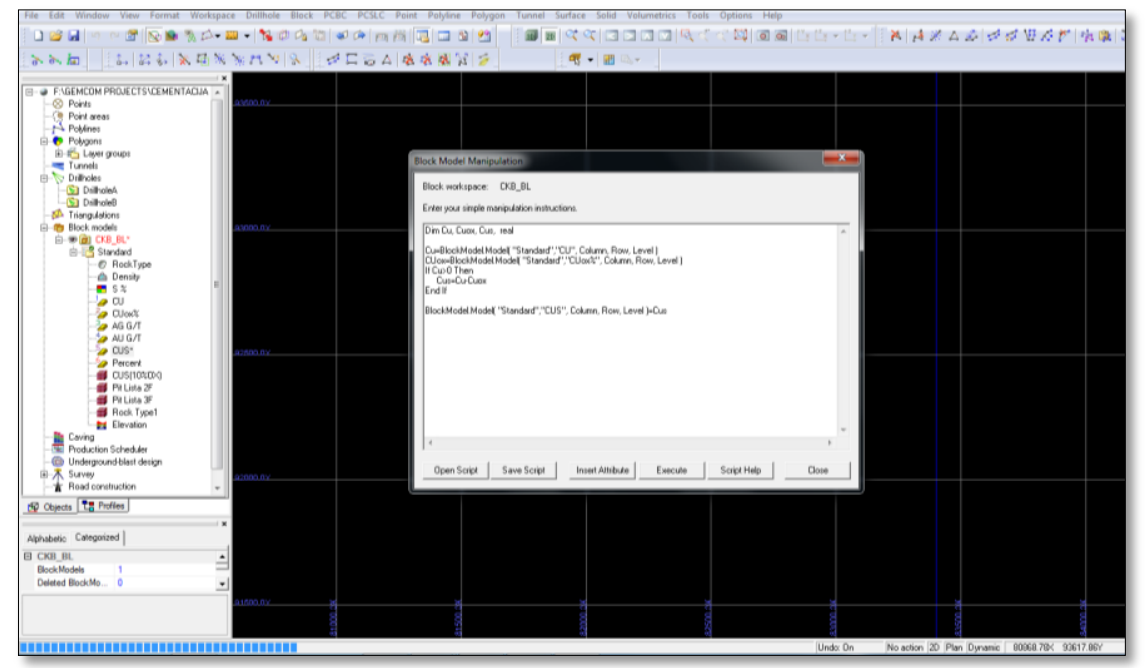

Sl. 6. Proces editovanja blok modela

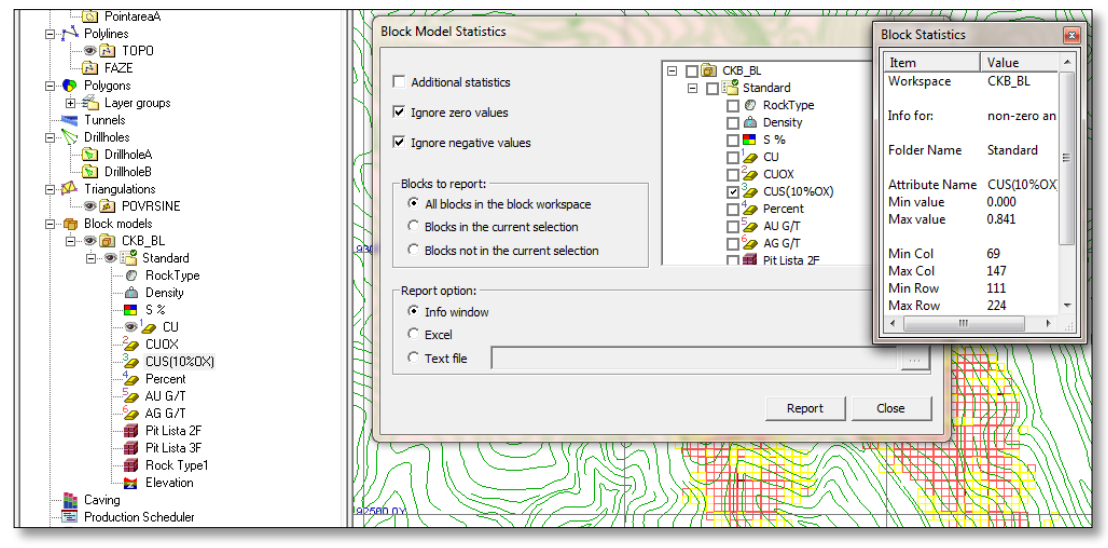

SI. 7. Statistika blok modela nakon editovanja skriptom, podaci su generisani u atributu koji se obrađuje 


\subsubsection{Tablica tipova skripta}

Tabela 1. Tipovi podataka

\begin{tabular}{|lllc}
\hline \multicolumn{1}{|c}{ Data Types } & & \\
\cline { 2 - 4 } Variable & & Type Declaration & Size \\
\hline Byte & & Dim BVar As Byte & 0 to 255 \\
Boolean & & Dim BoolVar As Boolean & True or False \\
String & $\$$ & Dim Str_Var As String & 0 to 65,500 char \\
Integer & $\%$ & Dim Int_Var As Integer & 2 bytes \\
Long & $\&$ & Dim Long_Var As Long & 4 bytes \\
Single & $!$ & Dim Sing_Var As Single & 4 bytes \\
Double & $\#$ & Dim Dbl_Var As Double & 8 bytes \\
Variant & & Dim X As Any & 8 bytes \\
Currency & & Dim Cvar As Currency & 4 bytes \\
Object & & Dim X As Object & 8 bytes \\
Date & Dim D As Date & size of each element \\
\hline
\end{tabular}

\subsubsection{Matematičke operacije koje se koriste u skriptama}

Tabela 2. Matematički operatori

\begin{tabular}{|l|l|}
\hline+ & Addition. \\
\hline- & Subtraction. \\
\hline$*$ & Multiplication. \\
\hline$/$ & Division. \\
\hline$\wedge$ & Exponentiation. \\
\hline LOG & Logarithm to base 10. \\
\hline LN & Logarithm to base E. \\
\hline$($ ) & Parentheses for grouping. \\
\hline
\end{tabular}

\subsection{Teoretske postavke manipulacije} podataka korišćenjem matematičkih i logičkih izraza

Ovaj tip manipulacije podacima koristi dva seta matematičkih izraza da manipuliše u zapisima koji su izabrani logičkim izrazima. Uslovna manipulacija ima sledeću formu:

If .> Logički izraz> je ISTIT (TRUE)

THEN Result $=\langle$ math expression $1>$

ELSE Result $=\langle$ math expression 2>

U logičkom izrazu, ako je logički izraz:

Ististinit (TRUE), onda GEMS koristi prvi set matematičkih izraza.

- True, then GEMS uses the first set of mathematical expressions.
- False, onda GEMS koristi drugi set matematičkih izraza.

Matematički izrazi ( Mathematical expressions)

Sastoje se od kombinacija sa jednim operatorom. Rezultat matematičkog izraza je uvek numerička vrednost.

Sintaksa ( Syntax).

Generalna sintaksa matematičkih izraza je u sledećoj formi:

$<$ Descriptor $>[<$ Operator $><$ Descriptor $>]$ 
gde je:

<Descriptor> sastoji se specifikatora polja varijabli ili konstanti.

<Operator> sastoji se bilo kog matematičkog i trigonometrijskog operatora.

Matematički operatori ( $\nabla$ Mathematical operators).

Matematički operatori (Mathematical operators) izvršavaju jednostavne matematičke operacije u numeričkim poljima fields (integer, real, double, coordinate, angle, date) i constama (integer i broj) i generišu numerčki rezultat. GEMS može da interpretira sledeće matematičke operatore:

Logički izraz. Uvek rezultira TRUE ili FALSE uslovima, a sastoji se od dva matematička izraza odvojenih logičkim izrazom.

\section{Logički operator.}

Logički izrazi se sastoje od matematičkih izraza i logičkih operatora. Rezultat logičkog izraza je bilo TRUE ili FALSE. Kada se koristi u manipulaciji podacima, rezultat TRUE se koristiti prvi matematički izraz i FALSE

se koristiti drugi matematički izraz.

$\nabla$ Syntaxa.

Uopštena sintaksa logičkih izraza ima sledeću formu:

$<$ Matematički izraz> <Operator> $<$ Matematički izraz> gde:

$<$ Matematički izraz> se sastoji iz matematičke jednačine kako je gore definisano

<Operator> se sastoji od logičkog operatora.

\section{Primeri.}

Tu su navedeni primeri logičkih izraza

"ASSAYS:GOLD" LE 1.5

("ASSAYS:TO" - "ASSAYS:FROM")

* COS ("ASSAYS:DIP") GT 10.0

\section{$\nabla$ Logički operatori.}

GEMS poseduje sledeće logičke operatore koji se koriste radi upoređenja dva izraza:
1. LT. Ako je rezultat prvog izraza (jne) manji od rezultata druge $j$-ne, logička operacija je TRUE.

2. LE. Ako je rezultat prve jednačine manji ili jednak rezultatu druge, logička operacija je TRUE.

3. GT. Ako je rezultat prve jednačine veći od rezultata druge jednačine, logička operacija je TRUE.

4. GE. Ako je rezultat prve jednačine veći ili jednak rezultatu druge jednačine, logička operacija je TRUE.

5. EQ. Ako je rezultat prve jednačine jednak rezultatu druge jednačine, logička operacija je TRUE.

6. NE.. Ako je rezultat prve jednačine nije jednak rezultatu druge jednačine, logička operacija je TRUE.

Postoje i drugi logički operatori koji mogu da se koriste kad se želi da se uporedi više od dva logička izraza istovremeno:

- AND. Kombinuje rezultate dva logička izraza. Krajnji rezultat je TRUE ako je rezultat oba logička izraza TRUE.

- OR. kombinuje rezultate dva logička izraza. Krajnji rezultat je istina ako nijedan od rezultata ova dve logička izraza nije TRUE.

Kada se želi da se koristi više od jednog logičnog izraza u jednom trenutku, svaki set logičkih izraza mora biti ograničen zagradama:

("ASSAYS:GOLD" GE 1.0) AND ("ASSAYS:SILVER" GE 5.0)

U matematičkim jednačinama i logičkim izrazima, Gems obavlja operacije u određenom redosledu.

\section{ZAKLJUČAK}

Skripta se koriste za manipulaciju podacima, geološkim i geodetskim u softverima koji koriste takve podatke, i da se na osnovu poznatih skupova podataka, kreiraju pod skupovi, prema određenim pravilima i 


\section{LITERATURA}

procedurama. To je vrsta makroa koji ima primenu i u drugim softverima koji operišu matematičkim izrazima i podacima, a ovde je prikazana upotreba u geološkom blok modelu u softveru Gemcom. Na osnovu poznatih podataka iz dva atributa koje uslovno možemo nazvati podskupovima blok modela u bazi geoloških podataka, npr. sadržaja metala, ako se radi o modelu metaličnog ležišta, može se kreirati blok model ekvivalentnog sadržaja $C u$ ukoliko u modelu postoje atributi više metala (Au, Ag, Mo, i dr), ili kao u primeru koji je obrađen u članku - ukoliko su urađene hemijske analiza na uzorcima jezgara na ukupan bakar $\mathrm{Cu}$, i oksidni (Cu ox), a potrebno je sračunati i sulfidni Cus, upotrebom scripa se na vrlo elegantan način to rešava.

Scripta u u stvari kratki zapisi linearnog programiranja kojima se pišu instrukcije kojima se vrši manipulacija podacima.
[1] GEMS Block Modeling Manuel, ver 6.1., Gemcom software International Inc. Vancouwer, BC. Canada, Jun. 2007

[2] Gems software "Help"

[3] B. Kolonja i saradnici, "Modeliranje ležišta savremenim alatima", Skripta iz projektovanja površinskih kopova Rudarsko-geološki fakultet Beograd, 2012.

[4] Z. Vaduvesković and others, "A Review of Previous Exploratory Works in the Complex Cerovo Cementacija and Data Processing in the Software Gemcom", 43. Oktobarsko savetovanje rudara i metalurga, Kladovo, Srbija, 12.-15. oktobra 2011., str. 515-520.

[5] Z. Vaduvesković, N. Vušović, D. Kržanović: "Analiza mogućnosti poboljšanja ekonomskih pokazatelja eksploatacije ležišta cementacija Kraku Bugaresku - Rudno polje Cerovo", Mining and Metallurgy Institute Bor, 1/2014., str. 25-36. 